\title{
A study to assess the socio-economic status of tea workers in selected tea estates of Sylhet district
}

\author{
J. K. Saha ${ }^{1}$, D. C. Acharjee ${ }^{2}$ and M. M. Rahman ${ }^{3}$
}

${ }^{1}$ Department of Agricultural Finance \& Banking, Sylhet Agricultural University, Sylhet; ${ }^{2}$ Department of Agribusiness, Bangabandhu Sheikh Mujibur Rahman Agricultural University, Gazipur; ${ }^{3}$ Department of Agricultural Marketing and Business Management, Sylhet Agricultural University, Sylhet

\begin{tabular}{|c|c|}
\hline ARTICLE INFO & Abstract \\
\hline $\begin{array}{l}\text { Received: } 12 \text { March } 2017 \\
\text { Accepted: } 17 \text { August } 2017\end{array}$ & \multirow{3}{*}{$\begin{array}{l}\text { The study was carried out to examine the socio-economic characteristics of tea plantation workers. A total } \\
\text { of } 50 \text { farmers from Sylhet district were selected randomly for data collection. The study showed that on an } \\
\text { average the size of family of the tea workers was } 4.69 \text { which is lower than agricultural labourer in } \\
\text { Bangladesh. The dependency ratio was found to be } 1.80 \text {.The literacy of the teaworkers was } 56 \text { percent out } \\
\text { of which } 43 \text { percent were primary level and } 13 \text { percent were secondary level. The average annual income } \\
\text { per surveyed household was Tk. } 75,615 \text { out of which } 83 \% \text { of the total income came from service as a tea } \\
\text { labourer while rest } 17 \% \text { derived from agriculture and non-agricultural sources. On an average, the annual } \\
\text { expenditure per family was Tk } 64,053 \text {.The study observed that } 88 \% \text { percent of the surveyed family } \\
\text { received loan from different NGO,s and while only } 12 \text { percent obtained from the bank. The analysis credit } \\
\text { utilization showed that } 41 \% \text { of the total loan was utilized in meeting repairing houses followed by } \\
\text { purchasing of cows ( } 25 \% \text { ) and business (13\%) respectively. The study showed that hundred percent roofs } \\
\text { of tea workers houses were made of tin. But } 58 \% \text { of the wall was made of brick while } 42 \% \text { was made of } \\
\text { mud. On an average } 47 \% \text { of the families reared poultry while } 63 \text { percent had livestock. Fifty four percent } \\
\text { of households grew vegetables in the study area. The major types of vegetables cultivate by tea workers in } \\
\text { the study area were bean, lalsak, chalkumra, gourd etc. Majority household had fruit trees in their } \\
\text { homestead. The study showed that most of the household consumed their home products. But only twenty } \\
\text { one percent of the households sold their fruits in the local market for cash flow. }\end{array}$} \\
\hline $\begin{array}{l}\text { Keywords: } \\
\text { Tea estate, Demographic status, } \\
\text { Cash flow transaction, Working } \\
\text { efficiency }\end{array}$ & \\
\hline $\begin{array}{l}\text { Correspondence: } \\
\text { D. C. Acharjee } \\
\text { (debasish.econ.sau@gmail.com) }\end{array}$ & \\
\hline
\end{tabular}

\section{Introduction}

Tea is a major cash crop as well as an important export earner of Bangladesh accounting for about $0.11 \%$ of the GDP by exporting tea (BTB, 2012). The industry and related trade are providing employment for about 0.15 million people, which are nearly $3.3 \%$ of the total industrial employment (Haque et al., 2012). At present the production of Bangladesh tea is increasing @ $1.16 \%$ per annum whereas consumption is increasing @6.5\% per annum (Saha et al. 2011). So in order to meet the increase domestic consumption productivity should be increased by increasing the efficiency of tea labourer. Productivity mainly depends upon the working efficiency of tea workers. A number of crop and management related factors were identified which influence labour efficiency. Agronomic study showed that possibility of reducing energy expenditure and heat load on tea pluckers and pointed to benefit of training them for enhancing energy use efficiency and puckers productivity (Jain, 1996).

Labour may be considered as raw material in tea production. Labour cost on different operations incurred $40.85 \%$ of the total cost (Saha et al., 2011). Among the different operational cost only plucking constitutes $44.33 \%$ of the total labour cost. Plucking $60 \mathrm{~kg}$ leaf per day doubles the wages and it saves $60 \%$ cost of plucking
(Jain, 1996.). The greater the efficiency of a tea plucker, the lower the cost of tea manufacturing. These are possible individually or jointly by proper training of the tea worker and supervision of the work. The socioeconomic condition of tea workers is very poor and the workers maintain a very low living standard. Therefore, to maintain the production efficiency of worker should be increased. .To increase the efficiency of the existing socio-economic condition of the tea worker is to be identified first. Once the socio-economic condition of the tea workers is known then it will be easier to solve their problems and as a result their efficiency can be increased. No systematic study on socio-economic condition has yet been undertaken neither by BTRI nor other organization till 2010. A planter should know the root level socio-economic condition of the tea workers, which will assist for improving the standard of living of the tea workers. Improved socio economic condition of the tea workers will contribute positively in the production system of the tea sector. Therefore, a tea estate management could increase per unit production of his own estate.

Tea has been accepted as one of the ten core commodities under integrated programme for commodities (IPC) of the United Nations Conference of trade and development (Sana, 1989.). The population of 
Bangladesh Tea Industry is about four lakhs including 1.5 lakhs are employed and rest are dependents (PDU, 2012 ).Of all the factors responsible for development and sustainability of Bangladesh Tea Industry, the hard labour of the tea workers at all operational stages upto to the end products cannot be ignored. Other factors are intensive cultivation, adoption of newer concepts and technology and efficiency in management (Alam, 1996). Major share of the profits is associated with the efficiency of the management and skillness of the tea workers.

Manpower development will enhance the tea output and improve the quality of tea and simultaneously reduce the cost of production (Hasib, 1996). The existing socioeconomic status of the workers will provide a view of the future in perspective of the past and serves as a base for tea policy decision (Misra, 1986). It will be a guideline for tea planters to know in how many ways and means and to what extent the efficiency of tea workers needs to increase in achieving the desired his/her output. It will help to take a balance between the development rate of tea industry and efficacy and skillness of tea workers. This study will help to improve the relationship between the management and tea workers. The major objective of the proposed study is to assess the socio-economic status of tea workers at Sylhet district. The specific objectives of the study are:

i. To identify the socio-economic characteristics of the tea workers.

ii. To evaluate the social and economic condition under which the tea workers work.

iii. To detect the ways and means to increase the efficiency of the tea workers

\section{Materials and Methods}

Two-stage stratified sampling method was followed in the study. In the first stage management-wise five estates, such as Lakatorrah. Malnicherra, Burjan, Khadim and Habibnagar tea estates were selected by simple random method. in such a way that it represents broad management viz, Sterling Company, National Tea Company, Private Limited Company, and Proprietary under which tea estates can be classified. An up-to-date list of the tea workers was collected from the individual tea estate for the purpose of selecting the tea workers. After that 50 tea workers were selected randomly from each of the five tea estates to collect requisite data. A draft questionnaire was prepared in the light of the objectives of the study. It was then pretested in the selected area among few tea workers. The final questionnaire was prepared after making necessary correction and modification.

Survey method was followed for collecting information from the respondent. After collection of data the interview schedule was checked and scrutinized to avoid irrelevant information. After collection of data a list of tables was prepared on the basis of aims and objectives of the study and processing, editing and coding of the data were done simultaneously. The tabulated data were then analyzed and condensed by using descriptive statistical techniques of averages, percentages, ratios etc. to obtain the result.

\section{Results and Discussion}

\section{Socio-economic Characteristics of tea workers}

Family size of the sampled tea workers: The Socioeconomic characteristics of the tea workers have an important bearing for increasing the efficiency of tea workers. The average household size of tea workers was found to be 4.69 out of which $28.83 \%$ was adult male, $28.38 \%$ was adult female while $42.79 \%$ t were children which was lower than the national average size 4.80 (BCS, 2008). It was also observed that the family size was comparatively lower than that of agricultural family size of Bangladesh (Elias, 1988). The dependency ratio of the tea workers was 1.80 (Table 1).

Educational level of the tea workers : On an average the literacy rate of the tea worker was $60.48 \%$ including those who had learnt introduction to Bengali alphabets and who could write and read letter (Table 2). Tea workers having primary and secondary education were 46.32 and 14.16 percent respectively. The study revealed that the level of literacy of the tea workers was fairly high as compared to Sylhet district. The study also suggested that rate of literacy among the tea plantation workers is not less than that of the agricultural laborer working in Bangladesh.

Occupational status of the tea workers : Occupation is one of the most important indicators of socio-economic status. The study showed that on an average $40.48 \%$ of the workers worked as a tea labourer in their respective tea estate (Table 3.). The dominance of occupation as a tea labourer is evident in all the tea estates. 
Table 1. Composition and family size of tea workers in some selected tea estates of Sylhet

\begin{tabular}{|c|c|c|c|c|c|c|}
\hline \multirow[t]{2}{*}{$\begin{array}{c}\text { Tea } \\
\text { Estates }\end{array}$} & \multicolumn{4}{|c|}{$\begin{array}{c}\text { Average number of family member } \\
\text { per estate }\end{array}$} & \multirow{2}{*}{$\begin{array}{l}\text { Average } \\
\text { Earning } \\
\text { member }\end{array}$} & \multirow[t]{2}{*}{$\begin{array}{l}\text { Dependency } \\
\text { ratio }\end{array}$} \\
\hline & Adult Male & Adult Female & Children & Total & & \\
\hline Lakatoorah & $\begin{array}{l}1.50 \\
(32.05)\end{array}$ & $\begin{array}{c}1.36 \\
(29.06)\end{array}$ & $\begin{array}{c}1.88 \\
(39.32)\end{array}$ & $\begin{array}{c}4.68 \\
(100)\end{array}$ & $\begin{array}{c}2.69 \\
(57 . .47)\end{array}$ & $\begin{array}{c}1.73 \\
(42.53)\end{array}$ \\
\hline Malnicherra & $\begin{array}{l}1.40 \\
(28.2)\end{array}$ & $\begin{array}{l}1.20 \\
(25.3)\end{array}$ & $\begin{array}{l}2.30 \\
(46.5)\end{array}$ & $\begin{array}{c}4.90 \\
(100)\end{array}$ & $\begin{array}{c}2.63 \\
(53.67)\end{array}$ & $\begin{array}{c}1.86 \\
(46.33)\end{array}$ \\
\hline Burjan & $\begin{array}{l}1.30 \\
(29.02)\end{array}$ & $\begin{array}{c}1.38 \\
(30.80)\end{array}$ & $\begin{array}{c}1.80 \\
(40.18)\end{array}$ & $\begin{array}{l}4.48 \\
(100)\end{array}$ & $\begin{array}{c}2.60 \\
(58.04)\end{array}$ & $\begin{array}{l}1.72 \\
(41.96)\end{array}$ \\
\hline Khadim & $\begin{array}{c}1.28 \\
(28.83)\end{array}$ & $\begin{array}{c}1,28 \\
(28.37)\end{array}$ & $\begin{array}{l}1.90 \\
(42.80)\end{array}$ & $\begin{array}{c}4.44 \\
(100)\end{array}$ & $\begin{array}{l}2.36 \\
(53.15)\end{array}$ & $\begin{array}{c}1,88 \\
(46.85)\end{array}$ \\
\hline Habibnagar & $\begin{array}{l}1.40 \\
(28.46)\end{array}$ & $\begin{array}{c}1.24 \\
(25.20)\end{array}$ & $\begin{array}{l}2.28 \\
(46.34)\end{array}$ & $\begin{array}{l}4.92 \\
(100)\end{array}$ & $\begin{array}{l}2.32 \\
(47.15)\end{array}$ & $\begin{array}{c}2.32 \\
(52.85)\end{array}$ \\
\hline All Estates & $\begin{array}{l}1.37 \\
(28.83)\end{array}$ & $\begin{array}{c}1.30 \\
(28.38)\end{array}$ & $\begin{array}{l}2.02 \\
(42.79)\end{array}$ & $\begin{array}{c}4.69 \\
(100)\end{array}$ & $\begin{array}{c}2.60 \\
(48.14)\end{array}$ & $\begin{array}{c}1.80 \\
(51.86)\end{array}$ \\
\hline
\end{tabular}

Figure within parentheses indicate percentages

Source: Field Survey 2015.

Table 2. Educational level of the tea workers in some selected tea estates of Sylhet

\begin{tabular}{|c|c|c|c|c|c|}
\hline \multirow{3}{*}{ Tea Estates } & \multicolumn{4}{|c|}{ Level of Education } & \multirow{3}{*}{ Grand Total } \\
\hline & \multirow[t]{2}{*}{ Illiterate } & \multicolumn{3}{|c|}{ Literate } & \\
\hline & & Primary & Secondary & Total & \\
\hline Lakatoorah & $\begin{array}{c}92 \\
(36.80)\end{array}$ & $\begin{array}{c}124 \\
(49.60)\end{array}$ & $\begin{array}{c}34 \\
(13.60)\end{array}$ & $\begin{array}{c}158 \\
(63.20)\end{array}$ & $\begin{array}{c}250 \\
(100)\end{array}$ \\
\hline Malnicherra & $\begin{array}{c}106 \\
(42.40)\end{array}$ & $\begin{array}{c}105 \\
(42.00)\end{array}$ & $\begin{array}{c}39 \\
(15.60)\end{array}$ & $\begin{array}{c}144 \\
(57.60)\end{array}$ & $\begin{array}{c}250 \\
(100)\end{array}$ \\
\hline Burjan & $\begin{array}{c}86 \\
(34.40)\end{array}$ & $\begin{array}{c}120 \\
(48.00)\end{array}$ & $\begin{array}{c}44 \\
(17.60)\end{array}$ & $\begin{array}{c}160 \\
(64.00)\end{array}$ & $\begin{array}{c}250 \\
(100)\end{array}$ \\
\hline Khadim & $\begin{array}{c}90 \\
(36.00)\end{array}$ & $\begin{array}{c}125 \\
(50.00)\end{array}$ & $\begin{array}{c}35 \\
(14.00)\end{array}$ & $\begin{array}{c}138 \\
(61.16)\end{array}$ & $\begin{array}{c}250 \\
(100)\end{array}$ \\
\hline Habibnagar & $\begin{array}{c}120 \\
(48.00)\end{array}$ & $\begin{array}{c}105 \\
(42.00)\end{array}$ & $\begin{array}{c}25 \\
(10.00)\end{array}$ & $\begin{array}{c}130 \\
(52.00)\end{array}$ & $\begin{array}{l}250 \\
(100)\end{array}$ \\
\hline All Estates & $\begin{array}{c}494 \\
(39.52)\end{array}$ & $\begin{array}{c}579 \\
(46.32)\end{array}$ & $\begin{array}{c}177 \\
(14.16)\end{array}$ & $\begin{array}{c}756 \\
(60.48)\end{array}$ & $\begin{array}{l}1250 \\
(100)\end{array}$ \\
\hline
\end{tabular}

Figure within parentheses indicate percentages

Source: Field Survey 2015.

Table 3. Occupational status of the tea workers in some selected tea estates of Sylhet

\begin{tabular}{|c|c|c|c|c|c|}
\hline \multirow[t]{2}{*}{ Tea Estates } & \multicolumn{5}{|c|}{ Occupational Status } \\
\hline & Tea Labour & Business & Student & Children & Total \\
\hline Lakatoorah & $\begin{array}{c}91 \\
(38.89)\end{array}$ & $\begin{array}{c}31 \\
(13.25)\end{array}$ & $\begin{array}{c}85 \\
(36.32)\end{array}$ & $\begin{array}{c}27 \\
(11.54)\end{array}$ & $\begin{array}{c}234 \\
(100)\end{array}$ \\
\hline Malnicherra & $\begin{array}{c}93 \\
(37.96)\end{array}$ & $\begin{array}{c}33 \\
(13.47)\end{array}$ & $\begin{array}{c}90 \\
(36.73)\end{array}$ & $\begin{array}{c}29 \\
(11.84)\end{array}$ & $\begin{array}{c}245 \\
(100)\end{array}$ \\
\hline Burjan & $\begin{array}{c}88 \\
(39.29)\end{array}$ & $\begin{array}{c}26 \\
(11,60)\end{array}$ & $\begin{array}{c}80 \\
(35.72)\end{array}$ & $\begin{array}{c}30 \\
(13.39)\end{array}$ & $\begin{array}{c}224 \\
(100)\end{array}$ \\
\hline Khadim & $\begin{array}{c}96 \\
(43.24)\end{array}$ & $\begin{array}{c}32 \\
(14.42)\end{array}$ & $\begin{array}{c}53 \\
(23.87)\end{array}$ & $\begin{array}{c}41 \\
(18.47)\end{array}$ & $\begin{array}{c}222 \\
(100)\end{array}$ \\
\hline Habibnagar & $\begin{array}{c}106 \\
(43.09)\end{array}$ & $\begin{array}{c}23 \\
(9.35)\end{array}$ & $\begin{array}{c}61 \\
(24.80)\end{array}$ & $\begin{array}{c}56 \\
(22.76)\end{array}$ & $\begin{array}{c}246 \\
(100)\end{array}$ \\
\hline All Estate & $\begin{array}{c}474 \\
(40.48)\end{array}$ & $\begin{array}{c}145 \\
(12.39)\end{array}$ & $\begin{array}{c}369 \\
(31.51)\end{array}$ & $\begin{array}{c}183 \\
(15.63)\end{array}$ & $\begin{array}{l}1171 \\
(100)\end{array}$ \\
\hline
\end{tabular}

Figure within parentheses indicate percentages

Source: Field Survey 2015.

Annual income and Expenditure of the tea workers: Economic status of the households is generally determined by the annual income. The study observed that on an average the annual income of the tea workers household was Tk.76695. Major Share of annual income of the households came from doing job as a tea worker out of which $66.67 \%$ obtained as cash money and $16.63 \%$ from kinds (Table 4). Annual income of the tea workers from agriculture was only $4.13 \%$ while it was about $12.52 \%$ from non-agricultural sector. On an average the annual expenditure of the tea worker household was Tk. 64053. The study revealed that 
highest expenditure was incurred for rice and wheat $(29.66 \%)$ followed by vegetables, fish, species, oil, meat and pulses respectively (Table 5). The cash flow transactions of the tea worker households showed that they are living in below subsistence level.

Table 4. Distribution of annual income tea workers in some selected tea estates of Sylhet (in taka)

\begin{tabular}{|c|c|c|c|c|c|c|}
\hline \multirow{3}{*}{ Tea Estates } & \multicolumn{6}{|c|}{ Annual Income in Taka } \\
\hline & \multicolumn{3}{|c|}{ Service } & \multirow{2}{*}{ Agriculture } & \multirow{2}{*}{ Non agriculture } & \multirow{2}{*}{ Grand Total } \\
\hline & Cash & Kinds & Total & & & \\
\hline Lakatoorah & $\begin{array}{c}45299 \\
(61.85)\end{array}$ & $\begin{array}{c}11731 \\
(16.02)\end{array}$ & $\begin{array}{c}57030 \\
(77.87)\end{array}$ & $\begin{array}{l}4073 \\
(5.56)\end{array}$ & $\begin{array}{l}12137 \\
(16.57)\end{array}$ & $\begin{array}{l}73240 \\
(100)\end{array}$ \\
\hline Malnicherra & $\begin{array}{c}56677 \\
(69.75)\end{array}$ & $\begin{array}{c}13211 \\
(16.26)\end{array}$ & $\begin{array}{c}69888 \\
(86.01)\end{array}$ & $\begin{array}{c}4442 \\
(5.47)\end{array}$ & $\begin{array}{c}6928 \\
(8.52)\end{array}$ & $\begin{array}{l}81258 \\
(100)\end{array}$ \\
\hline Burjan & $\begin{array}{c}47448 \\
(70.71)\end{array}$ & $\begin{array}{c}11881 \\
(17.71)\end{array}$ & $\begin{array}{c}59329 \\
(88.42)\end{array}$ & $\begin{array}{c}2727 \\
(4.06)\end{array}$ & $\begin{array}{c}5092 \\
(7.59)\end{array}$ & $\begin{array}{l}67097 \\
(100)\end{array}$ \\
\hline Khadim & $\begin{array}{c}50742 \\
(74.72)\end{array}$ & $\begin{array}{c}12080 \\
(17.79)\end{array}$ & $\begin{array}{c}62822 \\
(92.51)\end{array}$ & $\begin{array}{l}1312 \\
(1.93)\end{array}$ & $\begin{array}{c}3775 \\
(5.56)\end{array}$ & $\begin{array}{c}67909 \\
(100)\end{array}$ \\
\hline Habibnagar & $\begin{array}{c}51908 \\
(71.26)\end{array}$ & $\begin{array}{c}13982 \\
(19.19)\end{array}$ & $\begin{array}{c}65890 \\
(90.45)\end{array}$ & $\begin{array}{l}3126 \\
(4.29)\end{array}$ & $\begin{array}{c}3830 \\
(5.26)\end{array}$ & $\begin{array}{c}72846 \\
(100)\end{array}$ \\
\hline All Estates & $\begin{array}{c}50415 \\
(66.67)\end{array}$ & $\begin{array}{c}12577 \\
(16.63)\end{array}$ & $\begin{array}{c}62992 \\
(83.33)\end{array}$ & $\begin{array}{l}3136 \\
(4.13)\end{array}$ & $\begin{array}{c}9478 \\
(12.52)\end{array}$ & $\begin{array}{l}75695 \\
(100)\end{array}$ \\
\hline
\end{tabular}

Table 5. Distribution of annual expenditure tea workers in some selected tea estate of Sylhet (in taka )

\begin{tabular}{|c|c|c|c|c|c|c|c|c|c|}
\hline \multirow{2}{*}{ Tea Estates } & \multicolumn{9}{|c|}{ Annual Expenditure in taka } \\
\hline & Rice \& Wheat & Pulse & Fish & Meat & Vegetables & Oil & Species & Others & Total \\
\hline Lakatoorah & $\begin{array}{c}19448 \\
(30.06)\end{array}$ & $\begin{array}{c}3490 \\
(5.39)\end{array}$ & $\begin{array}{c}8065 \\
(12.46)\end{array}$ & $\begin{array}{c}4252 \\
(6.57)\end{array}$ & $9652(14.92)$ & $\begin{array}{l}5140 \\
(7.94)\end{array}$ & $\begin{array}{l}5744 \\
(8.88)\end{array}$ & $\begin{array}{c}8915 \\
(13.78)\end{array}$ & $\begin{array}{l}64706 \\
(100)\end{array}$ \\
\hline Malnicherra & $\begin{array}{c}17191 \\
(25.42)\end{array}$ & $\begin{array}{l}4061 \\
(6.01)\end{array}$ & $\begin{array}{c}9227 \\
(13.64)\end{array}$ & $\begin{array}{c}4762 \\
(7.04)\end{array}$ & $\begin{array}{c}11156 \\
(16.50)\end{array}$ & $\begin{array}{l}5115 \\
(7.56)\end{array}$ & $\begin{array}{l}6260 \\
(9.26)\end{array}$ & $\begin{array}{c}9854 \\
(14.57)\end{array}$ & $\begin{array}{c}67626 \\
(100)\end{array}$ \\
\hline Burjan & $\begin{array}{c}19685 \\
(31.96) \\
16712\end{array}$ & $\begin{array}{c}3499 \\
(5.68) \\
3782\end{array}$ & $\begin{array}{c}7685 \\
(12.48) \\
8163\end{array}$ & $\begin{array}{c}3654 \\
(5.93) \\
3596\end{array}$ & $\begin{array}{c}9195 \\
(14.93) \\
9127\end{array}$ & $\begin{array}{c}5028 \\
(8.18) \\
4625\end{array}$ & $\begin{array}{c}5827 \\
(9.46) \\
6350\end{array}$ & $\begin{array}{c}7026 \\
(11.41) \\
8055\end{array}$ & $\begin{array}{l}61599 \\
(100) \\
60500\end{array}$ \\
\hline Khadim & $\begin{array}{l}(27.63) \\
21945\end{array}$ & $\begin{array}{c}(6.25) \\
3589\end{array}$ & $\begin{array}{c}(13.49) \\
8213\end{array}$ & $\begin{array}{c}(5.94) \\
3794\end{array}$ & $\begin{array}{c}(15.23) \\
9469\end{array}$ & $\begin{array}{c}(7.64) \\
4695\end{array}$ & $\begin{array}{c}(10.50) \\
6049\end{array}$ & $\begin{array}{c}(13.31) \\
8084\end{array}$ & $\begin{array}{l}(100) \\
65838\end{array}$ \\
\hline $\begin{array}{l}\text { Habibnagar } \\
\text { All Estates }\end{array}$ & $\begin{array}{c}(33.33) \\
18997 \\
(29.66)\end{array}$ & $\begin{array}{c}(5.45) \\
3684 \\
(5.75)\end{array}$ & $\begin{array}{c}(12.47) \\
8271 \\
(12.91)\end{array}$ & $\begin{array}{c}(5.76) \\
4011 \\
(6.26)\end{array}$ & $\begin{array}{c}(9.19) \\
9737 \\
(15.20)\end{array}$ & $\begin{array}{l}(7.13) \\
4920 \\
(7.68)\end{array}$ & $\begin{array}{c}(9.19) \\
6046 \\
(9.44)\end{array}$ & $\begin{array}{c}(12.28) \\
8387 \\
(13.09)\end{array}$ & $\begin{array}{l}(100) \\
64053 \\
(100)\end{array}$ \\
\hline
\end{tabular}

Figure within parentheses indicate percentages

Source: Field Survey 2015.

Availability and utilization of Credit of tea workers : With the introduction of modern techniques in crop production and deterioration of worker's economic condition credit is regarded as an indispensable ingredient of production. Tea workers in Bangladesh are very poor and live below subsistence level. They cannot afford modern inputs unless cash money or inputs in kinds are provided. That is why the tea workers need external fund for their production. The study showed that 53 percent of the household received loan. The average amount of loan received per household was Tk. 11606. The study also depicts that 88 percent of the household received loan from different NGO while only 12 percent obtained loan from the bank. The analysis of credit utilization revealed that 41 percent of the total loan was utilized in meeting repairing of houses followed by purchasing of milk cows (25\%) and business (13\%) respectively (Table 6).
Social and demographic circumstance under which the tea workers work

Description of the tea workers houses : The average homestead area of the tea workers was 3.44 decimal. It was observed that 100 percent of the tea workers did not have their own houses. They generally live in the house given by individual tea estates. The study revealed that hundred percent roofs of the houses were made of tin. While 58 percent of the wall was made of brick while 42 percent of the wall was made of mud. On an average, the duration of living of a tea worker in a tea estate is about 34 years (Table 7 ).

Practice of livestock and poultry rearing : The field survey revealed that 47 percent household had poultry rearing (Table 8 ). It was observed that on an average 28 percent of household sold the poultry products. A further query on the types of livestock activities was as such: 
hen rearing $(43 \%)$, milk cow $(38 \%)$, and goat $(31 \%)$ respectively. The study also portrays that on an average
$60 \%$ of the tea workers consume the livestock product while $40 \%$ of the household sold the livestock product.

Table 6. Credit received by the tea workers in some selected tea estates of Sylhet

\begin{tabular}{|c|c|c|c|c|c|c|c|c|c|c|}
\hline \multirow[t]{3}{*}{ Tea Estates } & \multicolumn{2}{|c|}{$\begin{array}{c}\text { Credit received } \\
\text { ( in percent ) }\end{array}$} & \multirow{3}{*}{$\begin{array}{c}\text { Credit } \\
\text { received } \\
\text { per worker } \\
\text { ( in taka) }\end{array}$} & \multicolumn{4}{|c|}{ Purpose of credit } & \multicolumn{3}{|c|}{ Sources of Credit } \\
\hline & \multirow[b]{2}{*}{ Yes } & \multirow[b]{2}{*}{ No } & & \multirow{2}{*}{$\begin{array}{l}\text { Purchasing } \\
\text { Cows }\end{array}$} & \multirow{2}{*}{$\begin{array}{l}\text { Repairing } \\
\text { House }\end{array}$} & \multirow[t]{2}{*}{ Business } & \multirow[t]{2}{*}{ Others } & \multicolumn{2}{|c|}{ NGO } & \multirow[t]{2}{*}{ Bank } \\
\hline & & & & & & & & $\begin{array}{c}\text { ASHA \& } \\
\text { BRAC }\end{array}$ & FIWBP & \\
\hline Lakatoorah & 50 & 50 & 9760 & $10(40)$ & $06(24)$ & $04(16)$ & $05(20)$ & $22(88)$ & $02(8)$ & $01(04)$ \\
\hline Malnicherra & 44 & 56 & 20045 & $04(18)$ & $12(55)$ & $02(9)$ & $03(14)$ & $17(77)$ & $03(14)$ & $02(9)$ \\
\hline Burjan & 66 & 34 & 10333 & $05(15)$ & $13(40)$ & $04(12)$ & $11(33)$ & $10(30)$ & $17(52)$ & $06(18)$ \\
\hline Khadim & 50 & 50 & 7934 & $05(20)$ & $13(52)$ & $03(12)$ & $04(16)$ & $01(04)$ & $20(80)$ & $04(16)$ \\
\hline Habibnagar & 54 & 46 & 7339 & $09(33)$ & $10(37)$ & $04(15)$ & $04(15)$ & $06(22)$ & $19(70)$ & $02(08)$ \\
\hline All Estates & 53 & 47 & 11606 & $33(25)$ & $53(41)$ & $17(13)$ & $27(21)$ & $56(42)$ & $61(46)$ & $15(12)$ \\
\hline
\end{tabular}

Figure within parentheses indicate percentages

Source: Field Survey 2015.

Table 7. Description of the houses of the tea workers in some selected tea estates of Sylhet

\begin{tabular}{lcccccccc}
\hline Tea Estates & $\begin{array}{c}\text { Homestead area } \\
\text { (decimal ) }\end{array}$ & \multicolumn{2}{c}{$\begin{array}{c}\text { Ownership of the } \\
\text { House ( Percent ) }\end{array}$} & \multicolumn{2}{c}{$\begin{array}{c}\text { Types of Roof } \\
\text { (Percent) }\end{array}$} & \multicolumn{2}{c}{$\begin{array}{c}\text { Types of Wall } \\
\text { ( Percent) }\end{array}$} & $\begin{array}{c}\text { Period of residing at } \\
\text { the House ( Year) }\end{array}$ \\
\cline { 3 - 7 } Company & Own & Tin & Sungrass & Pucca & Mud & \\
\hline Lakatoorah & 3.50 & 100 & --- & 100 & --- & 50 & 50 & 31 \\
Manicherra & 3.52 & 100 & --- & 100 & --- & 80 & 20 & 37 \\
Burjan & 3.20 & 100 & --- & 100 & --- & 54 & 46 & 34 \\
Khadim & 3.20 & 100 & --- & 100 & --- & 50 & 50 & 32 \\
Habibnagar & 3.64 & 100 & --- & 100 & --- & 58 & 42 & 35 \\
All Estates & 3.44 & 100 & --- & 100 & --- & 58 & 42 & 34 \\
\hline
\end{tabular}

Source: Field Survey 2015.

Table 8. Number of household having livestock and poultry of the tea workers in some selected tea estates of Sylhet

\begin{tabular}{|c|c|c|c|c|c|c|c|c|c|}
\hline \multirow[t]{3}{*}{ Tea Estates } & \multicolumn{3}{|c|}{ Having Poultry } & \multicolumn{4}{|c|}{$\begin{array}{c}\text { Types of Livestock } \\
(\%)\end{array}$} & \multicolumn{2}{|c|}{$\begin{array}{c}\text { Pattern of use of Livestock } \\
\text { (in percent) }\end{array}$} \\
\hline & \multirow[b]{2}{*}{ Percent } & \multicolumn{2}{|c|}{ Pattern of use $(\%)$} & \multirow{2}{*}{$\begin{array}{l}\text { Milk } \\
\text { Cow }\end{array}$} & \multirow[t]{2}{*}{ Goat } & \multirow[t]{2}{*}{ Hen } & \multirow[t]{2}{*}{ Duck } & \multirow[t]{2}{*}{ Consumption } & \multirow[t]{2}{*}{ Sell } \\
\hline & & Consume & Sell & & & & & & \\
\hline Lakatoorah & 26 & 92 & 46 & 40 & 20 & 22 & -- & 75 & 45 \\
\hline Manicherra & 40 & 95 & 25 & 52 & 40 & 38 & 02 & 79 & 36 \\
\hline Burjan & 64 & 96 & 44 & 32 & 28 & 56 & 16 & 63 & 50 \\
\hline Khadim & 52 & 96 & 42 & 20 & 36 & 50 & 4 & 61 & 73 \\
\hline Habibnagar & 54 & 92 & 29 & 44 & 10 & 48 & 10 & 39 & 52 \\
\hline All Estates & 47 & 94 & 28 & 38 & 31 & 43 & 8 & 60 & 40 \\
\hline
\end{tabular}

Source: Field Survey 2015.

Vegetables grown, Sources and types of vegetables: On an average $54 \%$ percent of the households grew vegetables in their homestead area (Table 9). The study revealed that 84 percent of the household consumed their own grown vegetables and only $16 \%$ sold their vegetables at the adjacent local market. The study showed that majority of the household $(70 \%)$ purchased seed from local market for vegetables cultivation and 30 percent of household used own seeds for vegetables cultivation. The major types of vegetables grown by the household in the study area were bean (63\%), Sweet gourd (32\%), Piisak (31\%), Gourd (30\%), Chalkumra (29\%), Lalsak (28\%) respectively (Table 10). 
Table 9. Number of household grown vegetables and sources by the tea workers in some selected tea estates of Sylhet

\begin{tabular}{|c|c|c|c|c|c|c|}
\hline \multirow{3}{*}{ Tea Estates } & \multicolumn{3}{|c|}{ Vegetable grown } & \multirow{2}{*}{\multicolumn{3}{|c|}{ Sources of vegetables Seed $(\%)$}} \\
\hline & \multirow{2}{*}{ Percent } & \multicolumn{2}{|c|}{ Pattern of use (\%) } & & & \\
\hline & & Consume & Sell & Own & Local Market & Government \\
\hline Lakatoorah & 42 & 85 & 15 & 38 & 62 & -- \\
\hline Manicherra & 38 & 90 & 10 & 55 & 45 & -- \\
\hline Burjan & 52 & 95 & 5 & 15 & 85 & -- \\
\hline Khadim & 74 & 80 & 20 & 18 & 82 & -- \\
\hline Habibnagar & 62 & 80 & 20 & 33 & 67 & -- \\
\hline All Estates & 54 & 84 & 16 & 30 & 70 & -- \\
\hline
\end{tabular}

Source: Field Survey 2015.

Table 10. Types of vegetables grown by the tea workers in some selected tea estates of Sylhet

\begin{tabular}{lccccccccc}
\hline \multirow{2}{*}{ Tea Estates } & \multicolumn{7}{c}{ Types of vegetables grown (in percent) } \\
\cline { 2 - 9 } & Bean & Lalsak & Puisak & Danta & Gourd & Kachu & Chilli & Chalkumra & Sweet gourd \\
\hline Lakatoorah & 52 & 28 & 28 & 10 & 28 & 15 & 5 & 24 & 24 \\
Manicherra & 74 & 42 & 42 & 11 & 32 & 21 & 5 & 32 & 42 \\
Burjan & 58 & 31 & 31 & 9 & 31 & 8 & 8 & 42 & 31 \\
Khadim & 24 & 43 & 38 & 14 & 16 & 8 & 5 & 19 & 32 \\
Habibnagar & 21 & 16 & 23 & 16 & 45 & 13 & 7 & 23 & 43 \\
All Estates & 63 & 28 & 31 & 11 & 30 & 13 & 6 & 29 & 32 \\
\hline
\end{tabular}

Source: Field Survey 2015.

Belong fruit trees of the household : Table 11 showed that 78 percent of the household had fruit trees. It was observed from the table that only 21 percent of household sold their fruits at the adjacent local market. Data appended in the table indicated that majority of the household consumed their home produced fruits.

Table 11. Number of household having fruit trees of the tea workers in some selected tea estates of Sylhet

\begin{tabular}{lcccc}
\hline \multirow{2}{*}{ Tea Estates } & \multicolumn{2}{c}{ Having Fruit trees (in percent) } & \multicolumn{2}{c}{ Pattern of use of fruit trees (in percent) } \\
\cline { 2 - 5 } & Yes & No & 100 & 33 \\
\hline Lakatoorah & 80 & 20 & 100 & 30 \\
Manicherra & 80 & 20 & 100 & 19 \\
Burjan & 84 & 16 & 100 & 28 \\
Khadim & 66 & 34 & 100 & 29 \\
Habibnagar & 75 & 25 & 100 & 21 \\
All Estates & 78 & 22 & & 21 \\
\hline
\end{tabular}

Source: Field Survey 2015.

\section{Conclusion}

The average family size of tea workers is smaller as compared with agricultural labourer in Bangladesh. The family size can be reduced by intensive visit of family planning worker through motivation. The literacy percentage of tea workers is 64 percent. So introduction of new primary schools in the tea estates may increase the literacy percentage. The main occupation of the able working force is tea workers in their respective estates. They generally work from 7-30 a.m. to 2-30 p.m. they can do additional work in off time. They can earn money by manual work like pulling of rickshaws, van etc. They live from hand to mouth. They have no extra capital for purchasing rickshaw, cart, van etc. Short term supervised credit should be provided to them by any financial institution or any NGO with minimum interest rate. As a result, their per capita income will increase and consequently the working efficiency of tea workers will higher. Usually most of the tea workers grow vegetables in their homestead area. But they use local seed and their productivity is lower as compared with other agricultural farmers in Bangladesh. Therefore, short term supervised credit may be distributed to them at a minimum interest rate in time. This would enable them to procure improved seeds, which will help to enhance vegetable production. Consequently they will be able to consume these vegetables and maintain a good physique and better life; ultimately their working efficiency will increase. The present project was only a meager study to unveil some of the facts relating to the socio-economic status of our tea industry workers class. The findings would definitely encourage undertaking further detailed study on efficiency of tea workers vis-àvis their contribution to the productivity of the Bangladesh Tea Industry. 


\section{References}

Alam, A.F.M. 1996. Country Profile. Tea Industry of Bangladesh. Paper presented in the international conference held at Delhi in October, 1996. Pp 4.

BCS. Annual Report 2008. Bangladeshyio Cha Sansad. Agrabad Commercial Area, Chittagong.

Bangladesh Tea Board (BTB). 2012. Statistics on tea. Bangladesh Tea Board, 171-172 Baizid Bostami Road, Nasirabad, Chittagong.

Haque, S.K.L, Samad, M.A. and AFMB. 2012. Varietal improvement and multiplication of tea plant through tissue culture technique. Final report of the contract research project of Bangladesh tea Research Institute.

Jain, N.K. 1996. Economic parameters of tea in relation to global advances in tea science and technology. Paper presentation in the International Conference held at Delhi in October, 1996. p 4-6.

Misra, S.R. 1986. Tea Industry in India.Ashish Publishing House, 8/81 Punjabi Bagh, New Delhi. p 12.

PDU, 2007. Statistical Bulletin of Bangladesh. Project Development Unit. Bangladesh Tea Board, Srimangal, Maulvibazar.

Saha, J.K. and Gazi, M.S. 2001.An economic profile of the tea estates managed by Bangladesh Tea Board. A case study. Statistics and Economics Division, Srimangal, Maulvibazar.

Saha, J.K. and Saha, A. 2010. A study on growth analysis of tea and factors contributing to their production during pre and post Bangladesh Tea Rehabilitation period. Planters' Chronicle.106 (7): 06-21. The United Planters' Association of Southern India. The Nilgris, Tamilnadu, India.

Sana, D.L. 1989. An overview of the Tea Industry. Tea Journal of Bangladesh, 24(1): 37-38. 